Check for updates

Cite this: RSC Adv., 2017, 7, 47904

\title{
Extended-release of opioids using fentanyl-based polymeric nanoparticles for enhanced pain management $\uparrow$
}

\author{
Marina Kovaliov, ${ }^{\text {ab }}$ Shaohua Li, ${ }^{\text {ab }}$ Emrullah Korkmaz, ${ }^{c}$ Devora Cohen-Karni, ${ }^{\text {ab }}$ \\ Nestor Tomycz, ${ }^{\text {b }}$ O. Burak Ozdoganlar ${ }^{\text {cde }}$ and Saadyah Averick (D)*ab
}

\begin{abstract}
Opioid receptor agonists form the backbone of pharmacological pain management. The use of these drugs through the current delivery routes poses significant health risks, including abuse, addiction, respiratory depression, and death. Those risks can be alleviated through controlled release of opioids at therapeutic levels for prolonged periods. Biodegradable polymeric nanoparticles (NPs) have been utilized as controlled drug delivery vehicles due to their unique ability of presenting different molecules of interest at their surfaces. In this study, we focus on extended-release of the synthetic opioid fentanyl analogs for improved pain management. To this end, we report the formulation of fentanyl-bearing polylactide and polyglicolide NPs (Fen-PLA/PLGA NPS) with controlled size, surface features, and antinociceptive properties. Biocompatible Fen-PLA/PLGA NPs were formulated through opioid initiators Fen-OH and Fen-Ary-EtOH, to prepare opioid chain-end functional biodegradable polymers. The results demonstrate that a single subcutaneous dose of the prepared NPs delivers therapeutically relevant doses for up to six days in a mouse model of acute nociception without unwanted burst-release. To further our aim of precise administration of the novel opioid delivery systems into skin tissue, we envisioned and fabricated dissolvable microneedle arrays (MNAs) that integrate the formulated NPs at their tips. Our novel biohybrids, which can be delivered precisely and minimally-invasively using dissolvable MNAs, may be utilized to formulate opioids towards preventing overdose and abuse.
\end{abstract}

Received 31st July 2017

Accepted 2nd October 2017

DOI: $10.1039 / c 7 r a 08450 a$

rsc.li/rsc-advances

\section{Introduction}

Prescription opioids are a crucial component of modern medicine due to their antinociceptive effects. ${ }^{1,2}$ These drugs exert their action by acting as agonists to the mu opioid receptor (MOR), thereby inhibiting cAMP synthesis from ATP. ${ }^{3,4}$ Although very effective for pain management, opioids are associated with severe abuse and overdose potential due to the euphoria induced by binding to opioid receptors in the brain stem. ${ }^{5,6}$ To address this important problem, many attempts

\footnotetext{
${ }^{a}$ Neuroscience Disruptive Research Lab, Allegheny Health Network Research Institute, Allegheny General Hospital, Pittsburgh, Pennsylvania 15212, USA. E-mail: Saadyah. Averick@ahn.org; Tel: +1-412-359-4943

${ }^{b}$ Neuroscience Institute, Allegheny Health Network, Allegheny General Hospital, Pittsburgh, Pennsylvania 15212, USA

'Department of Mechanical Engineering, Carnegie Mellon University, 5000 Forbes Avenue, Pittsburgh, Pennsylvania 15213, USA

${ }^{d}$ Department of Biomedical Engineering, Carnegie Mellon University, 5000 Forbes Avenue, Pittsburgh, Pennsylvania 15213, USA

${ }^{e}$ Department of Materials Science and Engineering, Carnegie Mellon University, 5000 Forbes Avenue, Pittsburgh, Pennsylvania 15213, USA

$\dagger$ Electronic supplementary information (ESI) available: Additional ${ }^{1} \mathrm{H}$ NMR spectra, HPLC traces, GPC spectra, DLS data and in vivo activity data. See DOI: 10.1039/c7ra08450a
}

have been made to formulate opioids with antagonists or with abuse resistant excipients. ${ }^{7,8}$ Although many abuse resistant formulations have been developed, ${ }^{9-13}$ new opioid receptor agonists that can provide sustained pain relief, while limiting their abuse potential are needed. ${ }^{14-17}$

A potential avenue for realizing sustained and safe pain relief is the use of biodegradable micro- and nanoparticles (NPs). ${ }^{18-24}$ Commonly, controlled release is achieved by non-covalently encapsulating the therapeutic agent within the polymer matrix of biodegradable particles. ${ }^{21,25-29}$ As the particle degrades or is eroded the encapsulated drug is released. Among the most commonly used polymers for controlled release drug delivery are poly(lactic acid) (PLA), poly(glycolic acid (PGA)), and their copolymer poly(lactide-co-glycolide) (PLGA). PLA/PLGA/PGA polymeric nanoparticles (NPs) have been successfully used for systemic, oral, pulmonary, and transdermal routes for various medical conditions. ${ }^{30,31}$ The use of biodegradable NPs enables controlled drug release within the target site over a period of days or even weeks. ${ }^{22,32-35}$ However, there are several drawbacks to non-covalent encapsulation of drugs into a polymer matrix, including burst release and low amount of percent drug loading. ${ }^{36}$ The utilization of bioactive molecules as initiators for the ring-opening polymerization (ROP) of lactide and glycolide can overcome the drawbacks of non-covalently drug loaded 
polymeric nanocarriers. ${ }^{37}$ ROP allows for the synthesis of welldefined biodegradable polymers that have been widely used for the delivery of small molecule therapeutics. ${ }^{38-41}$

Fentanyl, a synthetic MOR agonist, presents a powerful candidate for formulation into controlled-release materials. ${ }^{42-46}$ Due to its high potency, the half maximal effective concentration $\left(\mathrm{EC}_{50}\right)$ value of fentanyl is 20 times lower than that of morphine for activation of MOR. Although oral administration of fentanyl is infeasible, due to a high first-pass metabolism, high potency and lipophilicity of fentanyl could promote new routes of administration. For instance, the prevailing transdermal therapeutic patch systems offer an excellent option for long-term treatment of cancer and chronic pain, achieving stable plasma concentrations over the treatment period. ${ }^{47,48}$ Unfortunately, abuse of transdermal fentanyl patches has led to several recently reported deaths. ${ }^{49-52}$ Furthermore, a single patch application cannot provide therapeutic doses for more than 72 hours. We posit that covalent incorporation of fentanyl into a nanocarrier can overcome its abuse liability by preventing extraction of the drug from the matrix. However, unlike other MOR agonists, such as morphine, fentanyl does not bear any available functional groups for conjugation into polymers or scaffolds. As such, to date, controlled-release applications of fentanyl have included its non-covalent incorporation into polymers, resulting in unwanted burst release when deployed. ${ }^{53-56}$ The incorporation of fentanyl into polymer chainends could potentially enable the extended-release of this therapeutic without unwanted burst-release. ${ }^{57}$

In our recent work, we demonstrated that fentanyl derivatives containing the acrylate "rigid" linking group retain MOR activity at low nanomolar levels. ${ }^{58}$ Based on that work, in this study, we used Fen-Acry-EtOH and Fen-OH ${ }^{59}$ for the fabrication and evaluation of Fen-PLA/PLGA NPs as a class of polymeric nanoparticle-based opioid delivery systems. Fen-PLA/PLGA polymers are prepared using fentanyl derivatives Fen-OH and Fen-Acry-OH via fentanyl initiated ROP of PLA and PLGA. Subsequent formation of NPs is achieved through double solvent evaporation method to obtain controlled-release formulations (Fig. 1).$^{60}$ The fentanyl derivatives are covalently linked to PLA/PLGA to better control their release kinetics as compared to NPs that are prepared by just encapsulation of the drug. In this way, we aim avoiding the unwanted large "burst" release kinetics in solutions that are typically showed by PLA/ PLGA matrices. ${ }^{53-56}$

The use of covalently linked fentanyl initiators and the modification of polymer chain length and nanoparticle size enables controlling the release kinetics and the loading of the drug. Furthermore, fentanyl initiators with different affinities to the MOR allow for tuning the potency of the released opioid for different pain severities. To the best of our knowledge, fentanylPLA/PLGA conjugate has not been reported yet.

To verify the antinociceptive effect of fentanyl NPs, we report the in vivo administration by subcutaneous injection into mice followed by hot-plate behavioral studies over a two-week period. Further, towards facilitating precise delivery of NPs into target tissues, we demonstrate successful fabrication of dissolvable microneedle arrays (MNAs) that incorporate the created NPs at
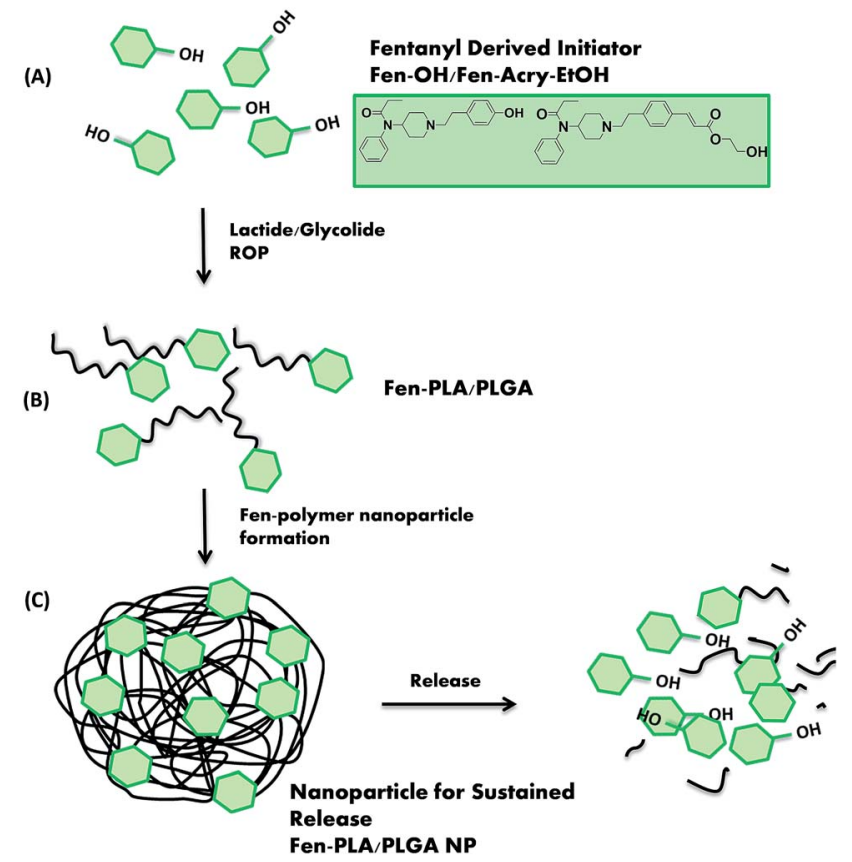

Fig. 1 Schematic representation of synthesis, formation and controlled release of fentanyl derivatives from Fen-PLA/PLGA NPs: (A) novel fentanyl based polymerization initiators Fen-OH and Fen-Acry$\mathrm{EtOH}$; (B) ROP polymerization of two monomers lactide or/and glycolide using fentanyl initiators to synthesize fentanyl contained polymers Fen-PLA/PLGA; (C) Fen-PLA/PLGA nanoparticle formulation and drug release under a range of physiologically relevant conditions.

their tips. The MNAs were created from carboxymethyl cellulose (CMC) through a previously described diamond micromilling/ elastomer molding/spin-casting fabrication method. ${ }^{61,62}$ The effectiveness of those MNAs in delivery of a myriad of therapeutics and vaccines has already been established. ${ }^{61-65}$ As such, we expect that dissolvable MNAs will enable effective delivery of opioid chain-end functional biodegradable polymers.

\section{Experimental section}

\section{Materials and methods}

$N$-Phenyl- $N$-piperidin-4-yl-propionannide was purchased from Astatech Inc. Lactide, glycolide, tin(II) 2-ethylhexanoate, tris(2-pyridylmethyl)amine (TPMA), 4-bromophenethyl bromide, 4-hydroxyphenethyl bromide, $N, N$-diisopropylethylamine, 2-hydroxyethyl acrylate, palladium(II) acetate, and ethylenebis(diphenylphosphine) were purchased from SigmaAldrich. All other reagents were purchased from SigmaAldrich and used without further purification. RP-HPLC spectra were collected using an 1260 Infinity Isocratic Pump with an ZirChrom®-PBD column $(50 \mathrm{~mm} \times 2.1 \mathrm{~mm}$ i.d., 3 micron). The mobile phase was acetonitrile/10 $\mathrm{mM}$ ammonium acetate $(\mathrm{v} / \mathrm{v}=45 / 55)$ with $0.1 \mathrm{mM}$ citrate $(\mathrm{pH} 4.4)$ and the temperature was $25{ }^{\circ} \mathrm{C}$. The flow rate was set at $0.3 \mathrm{~mL} \mathrm{~min}^{-1}$. Forskolin, IBMX, and Ro-20-1724 were purchased from SigmaAldrich. Chinese hamster ovary (CHO) cells expressing the human MOR were purchased from ChanTest Corporation, and 
cultured according to manufacturer's instructions. cAMP assay was purchased from Promega and used according to manufacturer's instructions. Hot plate was purchased from IITC Life Sciences. ${ }^{1} \mathrm{H}$ NMR was measured in $\mathrm{CDCl}_{3}$ or DMSO- $d_{6}$ on a Bruker Avance $500 \mathrm{MHz}$ spectrometer. Aqueous gel permeation chromatography (GPC) was performed on an Agilent GPC system equipped with a refractive index and diode array detector. An 1260 Infinity Isocratic Pump and an Agilent Bio SEC-3 column was used with running buffer of $100 \mathrm{mM}$ sodium phosphate with 0.2 vol\% trifluoroacetic acid $(\mathrm{pH}=2.5)$ at a flow rate of $1 \mathrm{ml}$ per min. Linear poly(ethylene oxide) $\left(M_{\mathrm{n}}=1400\right.$ $389500)$ standards was used for the calibration of the system. Dynamic Light Scattering (DLS), a NanoPlus3 from Micromeritics was used for nanoparticles measurement. Samples were prepared at $\sim 1 \mathrm{mg} \mathrm{mL} \mathrm{m}^{-1}$ in water.

\section{Synthesis of fentanyl analogs}

Synthesis of Fen-OH. To a solution of $N$-phenyl- $N$-piperidin4-yl-propionannide (norfentanyl) (0.93 g, $4.0 \mathrm{mmol}$ ) and 4hydroxyphenethyl bromide $(1.21 \mathrm{~g}, 6.0 \mathrm{mmol})$ in DMF $(15 \mathrm{~mL})$ was added $N, N$-diisopropylethylamine $(0.78 \mathrm{~g}, 6.0 \mathrm{mmol})$ and the reaction mixture was stirred at $60{ }^{\circ} \mathrm{C}$ for $24 \mathrm{~h}$. The reaction mixture was then cooled to room temperature and diethyl ether $(100 \mathrm{~mL})$ was added, and the organic phase was washed with $1 \mathrm{~N}$ $\mathrm{NaOH}(30 \mathrm{~mL} \times 3)$, water $(30 \mathrm{~mL} \times 3)$ and brine $(30 \mathrm{~mL} \times 3)$. The organic solution was dried over $\mathrm{MgSO}_{4}$, filtered, and concentrated under reduced pressure. The crude product was redissolved in diethyl ether, and pure Fen-OH were precipitated as $\mathrm{HCl}$ salt by addition of $\mathrm{HCl}$ in ethanol solution as a white solid (1.46 g, 96\%): ${ }^{1} \mathrm{H}$ NMR (500 MHz, $\left.\mathrm{CDCl}_{3}\right) \delta 7.45-7.35(\mathrm{~m}$, $3 \mathrm{H}), 7.09$ (dd, $J=8.5,8.5 \mathrm{~Hz}, 2 \mathrm{H}), 6.98(\mathrm{~d}, J=8.5 \mathrm{~Hz}, 2 \mathrm{H}), 6.76$ $(\mathrm{d}, J=8.5 \mathrm{~Hz}, 2 \mathrm{H}), 4.68(\mathrm{tt}, J=12.0,4.0 \mathrm{~Hz}, 1 \mathrm{H}), 2.99(\mathrm{~d}, J=$ $12.0 \mathrm{~Hz}, 2 \mathrm{H}), 2.67-2.47$ (m, 2H), 2.09 (td, $J=12.0,1.5 \mathrm{~Hz}, 2 \mathrm{H})$, $1.96(\mathrm{dd}, J=15.0,7.5 \mathrm{~Hz}, 2 \mathrm{H}), 1.80$ (d, $J=13.0 \mathrm{~Hz}, 2 \mathrm{H}), 1.44$ (q, $J$ $=12.0 \mathrm{~Hz}, 2 \mathrm{H}), 1.39-1.27(\mathrm{~m}, 2 \mathrm{H}), 1.03(\mathrm{t}, J=7.5 \mathrm{~Hz}, 3 \mathrm{H})$.

Synthesis of Fen-Br. $N$-phenyl- $N$-piperidin-4-ylpropionannide (norfentanyl, $0.93 \mathrm{~g}, 4.0 \mathrm{mmol}$ ) and 4-bromophenethyl bromide $(1.58 \mathrm{~g}, 6.0 \mathrm{mmol}$ ) was dissolved in $15 \mathrm{~mL}$ DMF, followed by addition of $N, N$-diisopropylethylamine $(0.78 \mathrm{~g}, 6.0 \mathrm{mmol})$. The reaction was kept stirring at $60{ }^{\circ} \mathrm{C}$ for $24 \mathrm{~h}$. The reaction mixture was cooled to room temperature before ethyl ether $(100 \mathrm{~mL})$ was added, and the organics were washed with $1 \mathrm{~N} \mathrm{NaOH}(30 \mathrm{~mL} \times 3)$, water $(30 \mathrm{~mL} \times 3)$ and brine $(30 \mathrm{~mL} \times 3)$. The organics were then dried over $\mathrm{MgSO}_{4}$ and concentrated under vacuum. The organics were redissolved in ethyl ether, and pure Fen-Br were precipitated as $\mathrm{HCl}$ salt by addition of $\mathrm{HCl}$ in ethanol solution (95\%): ${ }^{1} \mathrm{H}$ NMR (500 $\mathrm{MHz}$, $\left.\mathrm{CDCl}_{3}\right): \delta 7.41-7.35(\mathrm{~m}, 5 \mathrm{H}), 7.08(\mathrm{dd}, J=8.5,8.5 \mathrm{~Hz}, 2 \mathrm{H}), 7.02$ $(\mathrm{d}, J=8.5 \mathrm{~Hz}, 2 \mathrm{H}), 4.68(\mathrm{tt}, J=12.0,4.0 \mathrm{~Hz}, 1 \mathrm{H}), 3.00(\mathrm{~d}, J=$ $12.0 \mathrm{~Hz}, 2 \mathrm{H}), 2.70(\mathrm{~m}, 2 \mathrm{H}), 2.53(\mathrm{~m}, 2 \mathrm{H}), 1.93(\mathrm{dd}, J=15.0$, $7.5 \mathrm{~Hz}, 2 \mathrm{H}), 1.85(\mathrm{~d}, J=13.0 \mathrm{~Hz}, 2 \mathrm{H}), 1.6-1.4(\mathrm{~m}, 4 \mathrm{H}), 1.01(\mathrm{t}, J=$ $7.5 \mathrm{~Hz}, 3 \mathrm{H})$.

Synthesis of Fen-Acry-EtOH. To a solution of Fen-Br $(0.540 \mathrm{~g}$, $1.2 \mathrm{mmol})$ and hydroxyethyl acrylate $(0.740 \mathrm{~g}, 6.0 \mathrm{mmol})$ in mixture of $\mathrm{Et}_{3} \mathrm{~N}(2 \mathrm{~mL})$ and $\mathrm{DMF}(3 \mathrm{~mL})$ was added $\mathrm{Pd}\left(\mathrm{PPh}_{3}\right)_{2} \mathrm{Cl}_{2}$ ( $2 \mathrm{mg}, 0.003 \mathrm{mmol}$ ), and the reaction was stirring under $\mathrm{N}_{2}$ at
$140{ }^{\circ} \mathrm{C}$ for $24 \mathrm{~h}$. The reaction mixture was cooled to room temperature and $\mathrm{CH}_{2} \mathrm{Cl}_{2}(100 \mathrm{~mL})$ was added. The solution was filtered through a neutral alumina to remove the Pd catalyst. The filtrate was washed with $1 \mathrm{~N} \mathrm{NaOH}(30 \mathrm{~mL})$, water $(30 \mathrm{~mL})$, and brine $(30 \mathrm{~mL})$. The organic solution was dried over $\mathrm{MgSO}_{4}$, filtered, and concentrated under reduced pressure. The crude product was precipitated by addition of $\mathrm{HCl}$ in ethanol, and the precipitate was further purified by silica column chromatography (1:2 hexane/ethyl acetate) to afford the desired product as a white solid $(0.206 \mathrm{~g}, 85 \%):{ }^{1} \mathrm{H} \mathrm{NMR}\left(500 \mathrm{MHz}, \mathrm{CDCl}_{3}\right) \delta 7.69$ $(\mathrm{d}, J=16.0 \mathrm{~Hz}, 1 \mathrm{H}), 7.45-7.39(\mathrm{~m}, 5 \mathrm{H}), 7.24(\mathrm{~d}, J=7.0 \mathrm{~Hz}, 2 \mathrm{H})$, $7.11(\mathrm{dd}, J=8.5,8.5 \mathrm{~Hz}, 2 \mathrm{H}), 6.44(\mathrm{~d}, J=16.0 \mathrm{~Hz}, 1 \mathrm{H}), 4.81(\mathrm{tt}, J$ $=12.0,4.0 \mathrm{~Hz}, 1 \mathrm{H}), 4.35(\mathrm{t}, J=5.0 \mathrm{~Hz}, 2 \mathrm{H}), 3.90(\mathrm{t}, J=5.0 \mathrm{~Hz}$, $2 \mathrm{H}), 3.63(\mathrm{~d}, J=12.0 \mathrm{~Hz}, 2 \mathrm{H}), 3.23(\mathrm{~m}, 2 \mathrm{H}), 3.14(\mathrm{~m}, 2 \mathrm{H}), 2.84$ $(\mathrm{td}, J=12.0,1.5 \mathrm{~Hz}, 2 \mathrm{H}), 2.2-1.9(\mathrm{~m}, 6 \mathrm{H}), 1.02(\mathrm{t}, J=7.5 \mathrm{~Hz}, 3 \mathrm{H})$.

\section{Synthesis of fentanyl polymers}

Synthesis of Fen-PLA. Fen-OH (100 mg, $0.28 \mathrm{mmol})$, lactide (2.1 g, $14.6 \mathrm{mmol})$, and stannous octoate $(20 \mathrm{mg}, 49 \mu \mathrm{mol})$ was added to a Schlenk flask equipped with a magnetic stir bar and a rubber septum. The flask was air-tightly sealed and was purged with dry $\mathrm{N}_{2}$ gas for $1 \mathrm{~h}$. The reaction mixture was then heated at $140{ }^{\circ} \mathrm{C}$ and stirred for $2 \mathrm{~h}$. The reaction was cooled to room temperature and dichloromethane $(10 \mathrm{~mL})$ was added to dissolve the product. The polymer was purified by precipitation from mixture of methanol and water. Yield: $90 \% .{ }^{1} \mathrm{H}$ NMR (500 MHz, $\mathrm{CDCl}_{3}$ ): $\delta$ 5.3-5.1 (br), 4.39 (s), 1.6-1.4 (br). GPC: $M_{\mathrm{n}}=9500, M_{\mathrm{w}} / M_{\mathrm{n}}=1.35$.

Synthesis of Fen-PLGA. Fen-OH $(80 \mathrm{mg}, 0.23 \mathrm{mmol})$, lactide $(1.0 \mathrm{~g}, 6.9 \mathrm{mmol})$, glycolide $(1.0 \mathrm{~g}, 8.6 \mathrm{mmol})$, and stannous octoate ( $32 \mathrm{mg}, 79 \mu \mathrm{mol})$ was added to a Schlenk flask equipped with a magnetic stir bar and a rubber septum. The flask was airtightly sealed and was purged with dry $\mathrm{N}_{2}$ gas for $1 \mathrm{~h}$. The reaction mixture was then heated at $180{ }^{\circ} \mathrm{C}$ and stirred for $2 \mathrm{~h}$. The reaction was cooled to room temperature and dichloromethane $(10 \mathrm{~mL})$ was added to dissolve the product. The solution was filtered and was dialyzed against methanol and acetone and the polymer was precipitated from methanol/water. Yield: $85 \%$. ${ }^{1} \mathrm{H}$ NMR (500 MHz, $\mathrm{CDCl}_{3}$ ): $\delta$ 5.3-5.1 (br), 5.0-4.6 (br), 1.6-1.4 (br). GPC: $M_{\mathrm{n}}=14000, M_{\mathrm{w}} / M_{\mathrm{n}}=2.45$.

Synthesis of Fen-Acry-PLGA. Fen-Acry-OH $(22 \mathrm{mg}, 0.05$ mmol), lactide (1.0 g, $6.9 \mathrm{mmol})$, glycolide $(1.0 \mathrm{~g}, 8.6 \mathrm{mmol})$, and stannous octoate $(20 \mathrm{mg}, 49 \mu \mathrm{mol})$ was added to a Schlenk flask equipped with a magnetic stir bar and a rubber septum. The flask was air-tightly sealed and was purged with dry $\mathrm{N}_{2}$ gas for $1 \mathrm{~h}$. The reaction mixture was then heated at $160{ }^{\circ} \mathrm{C}$ and stirred for $20 \mathrm{~min}$. The reaction was cooled to room temperature and dichloromethane $(10 \mathrm{~mL})$ was added to dissolve the product. The solution was filtered and was dialyzed against methanol and acetone. ${ }^{1} \mathrm{H}$ NMR (500 MHz, $\mathrm{CDCl}_{3}$ ): $\delta$ 5.3-5.1 (br), 5.0-4.6 (br), 1.6-1.4 (br). GPC: $M_{\mathrm{n}}=16300, M_{\mathrm{w}} / M_{\mathrm{n}}=1.65$.

\section{Formation of fentanyl polymer nanoparticles}

Fentanyl polymer (20 mg) was dissolved in $2 \mathrm{~mL}$ acetonitrile. The mixture was slowly injected via a syringe pump with a speed of $20 \mu \mathrm{L} \mathrm{min} \mathrm{m}^{-1}$ into $15 \mathrm{~mL} 0.3 \%$ poly(vinyl alcohol) solution 
under rapid stirring. After the injection, the solution was continued to be stirred at room temperature overnight for the evaporation of the organic solvent. The NPs were collected by centrifugation at $\sim 4000 \mathrm{rpm}$ and was further purified by dialysis against ultrapure water.

\section{Fen-OH-PLGA nanoparticles formation}

An emulsification solvent evaporation method was used to prepare Fen-OH loaded PLGA nanoparticles, $100 \mathrm{mg}$ of PLGA $75: 25$, and $10 \mathrm{mg}$ of Fen-OH were dissolved in $11 \mathrm{~mL}$ DCM. The mixture was slowly injected via a syringe pump with a speed of $100 \mu \mathrm{L} \mathrm{m^{-1 }}{ }^{-1}$ into $85 \mathrm{~mL} 0.3 \%$ poly(vinyl alcohol) (PVA) solution under rapid stirring. After the injection, the solution was continued to be stirred at room temperature for 1-2 $\mathrm{h}$ for the evaporation of the organic solvent. The NPs were collected by centrifugation at $\sim 4000 \mathrm{rpm}$.

\section{Morphology of Fen-PLA/PLGA NPs}

A drop of NPs suspension was placed on a glass slide and air dried for $6 \mathrm{~h}$. Subsequently, the slides were imaged using an environmental scanning electron microscope (Quanta 600 ESEM) to observe the integrity of the NPs. The ESEM with its field emission capability allowed us to obtain the images of the NPs without a conductive coating.

\section{MOR activation and $\mathrm{IC}_{50}$ value determination (cAMP inhibition studies)}

CHO cells expressing the Human MOR were cultured according to the manufacturer's protocol. Cells were plated at $90 \%$ confluency in white 96-well plates. Prior to the cAMP assay, induction buffer $(1 \times$ PBS, $500 \mu \mathrm{M}$ IBMX, $100 \mu \mathrm{M}$ Ro-20-1724) was added to each well, and incubated at $37{ }^{\circ} \mathrm{C}$ for 30 minutes. Cells were incubated for additional $30 \mathrm{~min}$ with the opioid-derivative at a range of concentrations $\left(10^{-11}-10^{-4}\right)$ with $25 \mu \mathrm{M}$ Forskolin. cAMP levels were determined using a cAMPGlo kit from Promega based on the manufacturer's instructions. DAMGO was used as a positive control.

\section{Biocompatibility assay}

SH-SY5Y neuroblastoma cells (GenTarget) were cultured according to the manufacturer's protocol. Cells were plated at $90 \%$ confluency in white 96-well plates. Prior to the ATP assay, the tested compound was added to each well at final concentrations ranging from $0.5-1 \mathrm{mg} \mathrm{mL}^{-1}$, as indicated, in triplicates, and incubated at $37^{\circ} \mathrm{C}$ for $48 \mathrm{~h}$. ATP levels were determined using a CellTiter-Glo® Luminescent Cell Viability Assay kit from Promega according to the manufacturer's protocol, and read using a luminometer (Cytation 3, Biotek). Untreated cells in culturing media (no polymer) were used as a control.

\section{Fen-OH/Fen-Acry-OH release rates}

The release rates were measured at $\mathrm{pH}=7.4$, and 2 . In vitro cumulated Fen-OH/Fen-Acry-OH concentration was measured using HPLC. For the in vitro studies, about $3 \mathrm{mg}$ of fentanyl NPs were suspended in $2.0 \mathrm{~mL}$ of release medium (PBS, phosphate buffer solution of $\mathrm{pH} 7.4$ and $\mathrm{KCl} / \mathrm{HCl}$ buffer $\mathrm{pH} 2(1.5 \mathrm{mg}$ $\left.\mathrm{mL}^{-1}\right)$ ). The sealed Eppendorf tubes were then slowly rotated at $37^{\circ} \mathrm{C}$. At predetermined time intervals (up to 50 days), the tubes were centrifuged at $14000 \mathrm{rpm}$ for $2 \mathrm{~min}$ and $100 \mu \mathrm{L}$ aliquots of medium were taken from supernatant. Maximum Fen-OH and Fen-Acry-OH in vitro release was determined by placing fentanyl nanoparticles in $1 \mathrm{~N} \mathrm{NaOH}$ overnight at $37^{\circ} \mathrm{C}$. PLGA and PLA are fully degradable, thereby releasing all Fen-OH. Samples were centrifuged and Fen-OH/Fen-Acry-OH content in the supernatant was analyzed by HPLC. HPLC spectra were collected using 1260 Infinity Isocratic Pump with ZirChrom®PBD column $(50 \mathrm{~mm} \times 2.1 \mathrm{~mm}$ i.d., 3 micron $)$. The mobile phase was acetonitrile/10 $\mathrm{mM}$ ammonium acetate $(\mathrm{v} / \mathrm{v}=45 / 55)$ with $0.1 \mathrm{mM}$ citrate $(\mathrm{pH} 4.4)$ at $35{ }^{\circ} \mathrm{C}$. The flow rate was set at $0.3 \mathrm{~mL} \mathrm{~min}^{-1}$. Ten microliters of samples or calibration standards were injected into the HPLC column. Detection was carried out by monitoring absorbance signals at $280 \mathrm{~nm}$. The elution period was $10 \mathrm{~min}$ and the retention of $\mathrm{Fen}-\mathrm{OH}$ was about $2 \mathrm{~min}$ and of Fen-Acry-OH about $1 \mathrm{~min}$. HPLC was calibrated with standard solutions of 0.06 to $60 \mu \mathrm{g} \mathrm{mL} \mathrm{m}^{-1}(0.0017$ to $0.17 \mathrm{mM})$ of Fen-OH and Fen-Acry-OH (correlation coefficient of $R^{2}=0.9999$ ).

\section{Hot plate withdrawal assay}

All animal care was performed in compliance with the Guide for the Care and Use of Laboratory Animals prepared by the Institute of Laboratory Animal Resources and published by the National Institutes of Health (NIH Publication no. 86-23), and was approved by Institutional Animal Care and Use Committee (IACUC) at the Allegheny Health Network. CD-1 mice were purchased from Charles Rivers Laboratories (Male, $30 \mathrm{~g}$ ) and housed for 1 week prior to initiation of experiments. $30 \mathrm{~min}$ prior to placement on a $55{ }^{\circ} \mathrm{C}$ hotplate (IITC Life Sciences), mice were dosed subcutaneously with fentanyl, saline or fentanyl derivatives. Mice were placed on the hot plate and monitored for hind paw licking or jumping. At the first sign of these symptoms, the time was marked, and animals were removed from the hot plate and euthanized. Animals that did not show a response after 30 seconds were removed and euthanized.

\section{Tip-loaded dissolvable MNAs incorporating fentanyl-polymer nanoprecipitates}

Tip-loaded dissolvable MNAs with obelisk-shaped microneedles that incorporate opioid biohybrid systems were created from low viscosity sodium CMC (cat\# C5678, Sigma-Aldrich) using our micromilling/elastomer/molding/spin-casting approach. ${ }^{38}$ Briefly, the mastermolds were manufactured from a wear resistant polymer, poly(methyl methacrylate), using the micromilling technique. ${ }^{38}$ The mastermolds were then used to produce elastomer molds from polydimethylsiloxane (PDMS, SYLGARD® 184, Dow Corning). Subsequently, tip-loaded dissolvable MNAs with embedded fentanyl polymer nanoparticles were fabricated using a two-step spin-casting technique. To this end, first, the nanoparticles were suspended in $2 \%$ CMC solution. Next, $20 \mu \mathrm{L}$ of this solution was dispensed over each of the PDMS molds and centrifuged for $5 \mathrm{~min}$ at 
$4700 \mathrm{rpm}$ at $22{ }^{\circ} \mathrm{C}$ to fill the obelisk-shaped cavities of the PDMS mold. Once the excessive bioactive cargo was recovered, the PDMS molds were again centrifuged for $30 \mathrm{~min}$ at $22^{\circ} \mathrm{C}$ and at $4700 \mathrm{rpm}$ to ensure that the dry bioactive cargo is located at the tip portion of the obelisk-shaped cavities. After completing the tip loading step, PDMS molds were loaded with 25 wt\% CMC hydrogel to fill the obelisk-shaped cavities and to form a backing layer for the MNAs. For each tip-loaded CMC-MNA, $75 \mu \mathrm{L}$ of CMC-hydrogel was placed over the each of the PDMS molds. The CMC-hydrogel loaded PDMS molds were then centrifuged for $4 \mathrm{~h}$ at $22{ }^{\circ} \mathrm{C}$ and at $3500 \mathrm{rpm}$ to obtain full density, dry MNAs.

\section{Results and discussion}

\section{Synthesis and biological evaluation of fentanyl ROP initiators}

To design the fentanyl initiators for ROP, we wanted to incorporate the hydroxyl group, providing a reactive group to grow biodegradable polymers. Recently, we prepared a small library of fentanyl analogs by utilizing a novel "rigid" acrylate group. These compounds were evaluated in vitro by $\mathrm{Mu}$ opioid receptor activation in a live cell cAMP inhibition assay and most resulted in lower $\mathrm{EC}_{50}$ values (higher activity) than morphine $\left(\mathrm{EC}_{50} 24\right.$ $\mathrm{nM}) .{ }^{58}$ Based on that work, we used Fen-Acry-EtOH and Fen-OH, known fentanyl metabolite, ${ }^{59}$ as ROP initiators. Although there is a ten folds decrease in $\mathrm{EC}_{50}$ for the activation of the MOR, this modification allows for the direct incorporation of fentanyl into the chain-end of biodegradable polymers. Fen-OH was prepared using commercially available precursors as shown in Scheme 1. Norfentanyl was reacted with 4-hydroxyphenethyl bromide to afford Fen-OH through direct alkylation of piperidine moiety. The pure product was isolated as $\mathrm{HCl}$ salt in 95\% yield. The structure and purity of Fen-OH were determined by NMR and RP-HPLC. Fen-Acry-EtOH was synthesized by Pd catalyzed Heck reactions from Fen-Br, a novel fentanyl derivative. Fen-Br was coupled with hydroxyethyl acrylate to afford Fen-Acry-EtOH in high yield as was previously published. ${ }^{58}$

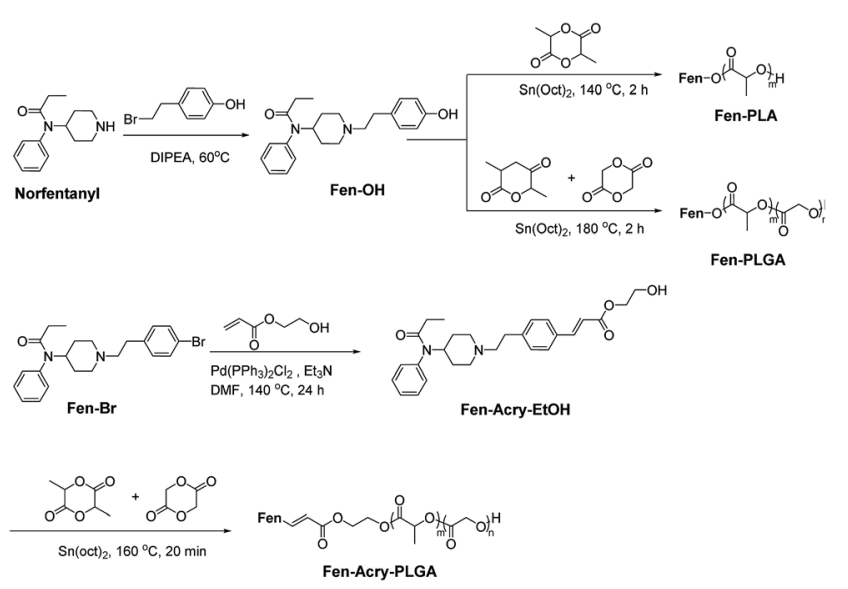

Scheme 1 Synthesis of fentanyl initiators and fentanyl containing biodegradable polymers.
The mechanism of antinociception exerted by opioids through activation of MOR leading to inhibition of cAMP synthesis from ATP. MOR activation assay was used to determine the $\mathrm{EC}_{50}$ values of the fentanyl initiators. cAMP inhibition studies were performed by incubation of the fentanyl initiators at a range of concentrations $\left(10^{-11}-10^{-4} \mathrm{M}\right)$ with forskolin treated MOR expressing (CHO) cells. DAMGO, a synthetic opioid agonists peptide, was used as a standard in MOR activation assays, and fentanyl was used as reference (Fig. 2). The $\mathrm{EC}_{50}$ of Fen-OH and Fen-Acry-EtOH was found to be $60 \mathrm{nM}$ and $22.8 \mathrm{nM}$, respectively. As such, either of these fentanyl derivatives provide the opportunity to tune the antinociceptive potential of resultant fentanyl polymer hybrids by modification of the linking group between fentanyl and PLGA.

\section{Synthesis of fentanyl containing biodegradable polymers}

Fentanyl terminated PLA (Fen-PLA) and PLGA (Fen-PLGA) were prepared under standard conditions using stannous octoate as a catalyst (Fig. 3). The ratio of [monomer] : [initiator] was set at around $50: 1$ to afford polymers with targeted molecular weight $\left(M_{\mathrm{n}}\right)$ of $\sim 8000 \mathrm{~g} \mathrm{~mol}^{-1}$. Both polymers were obtained with good yields and molecular weights (Table 1). The structure of each polymer was confirmed by ${ }^{1} \mathrm{H}$ NMR (Fig. 3 and S7 in ESI $\dagger$ ). The $M_{\mathrm{n}}$ of the polymers measured by gel permeation chromatography (GPC) was higher than the theoretical molecular weight, indicating a non-complete initiation from the Fen-OH during the polymer growth. Fen-Acry-PLGA was also grown from the Fen-R-EtOH precursor under adjusted conditions. The ratio of [monomer]: [initiator] was increased to $\sim 300: 1$ to ensure sufficient initiation from the Fen-Acry-EtOH. The polymerization reaction time was shortened, preventing from the polymer to reach its theoretical $M_{\mathrm{n}}$, so that all opioid terminated polymers had similar molecular weights. The structure of Fen-AcryPLGA was confirmed by ${ }^{1} \mathrm{H}$ NMR and the $M_{\mathrm{n}}$ was measured to be $16300 \mathrm{~g} \mathrm{~mol}^{-1}$ by GPC (Fig. S10 in ESI $\dagger$ ).

To evaluate the potential of Fen-containing polymers in vitro, Fen-PLA/PLGA and Fen-Acry-PLGA NPs were prepared by nanoprecipitation method. Both the size and zeta potential of all NPs were measured, and the results are presented in Table 1 . The size of Fen-PLA NPs was measured to be $\sim 360 \mathrm{~nm}$, while the sizes of Fen-PLGA and Fen-Acry-PLGA were around $500 \mathrm{~nm}$. As expected for PLA/PLGA NPs, a negative zeta potential was also

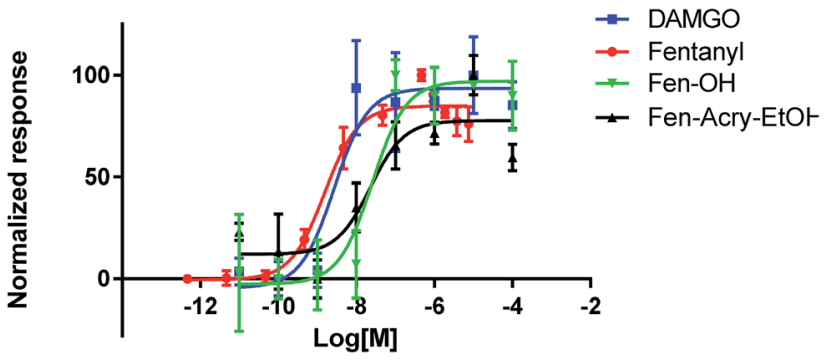

Fig. 2 Activation of MOR by synthesized fentanyl ROP initiators (Fen$\mathrm{OH}$, Fen-Acry-EtOH), DAMGO and fentanyl by using CAMP-GloTM assay. 

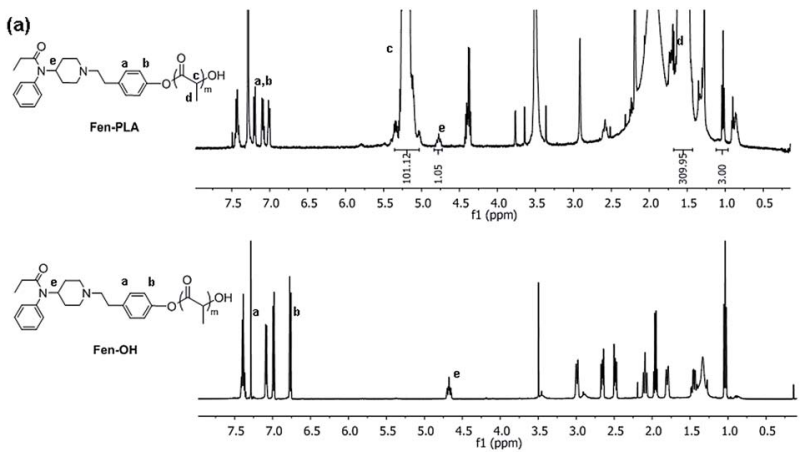

(b)

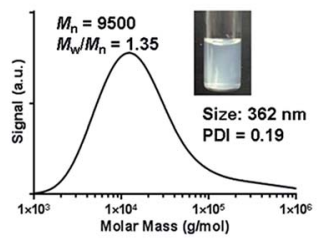

(c)

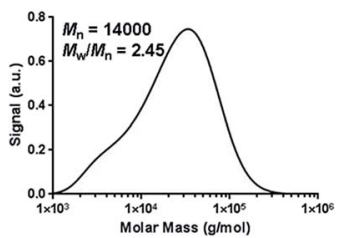

Fig. 3 Characterization of the opioid chain-end functional biodegradable polymers: (a) ${ }^{1} \mathrm{H}$ NMR of Fen-PLA and Fen-OH; (b) GPC of Fen-PLA and Fen-PLA nanoparticles in aqueous suspension; and (c) GPC of Fen-PLGA nanoparticles.

observed for Fen-PLA/PLGA NPs $(-20 \mathrm{mV},-22 \mathrm{mV},-33 \mathrm{mV})$. Zeta potential value is indicator of stability of NPs against agglomeration. All Fen-PLA/PLGA NPs showed strong negative zeta potential documenting their stable nature. The biocompatibility of the NPs was evaluated in a neuronal cell line. ${ }^{66,67}$ The morphology of NPs was investigated by SEM analysis. As displayed in Fig. 4 and $\mathrm{S} 18 \dagger$ all NPs showed a spherical shape with smooth surface, and no visible cracks or voids. The partial fusion detected in some nanoparticle samples takes place during analysis, where many NPs congregate together.

The biocompatibility assay was performed by incubating $\mathrm{SH}-$ SY5Y neuroblastoma cells with the fentanyl derived polymer NPs for 48 hours. As shown in Fig. 5, all three fentanyl-polymer NPs were found to be fully biocompatible in the entire tested range $\left(0.1 \mu \mathrm{g} \mathrm{mL}^{-1}\right.$ to $\left.300 \mathrm{mg} \mathrm{mL}^{-1}\right)$, since cellular ATP levels with respect to the control were maintained.

\section{Controlled release in vitro}

The controlled-release profile of our covalent fentanyl derivatives is central to our novel opioid delivery system. Two crucial factors that can influence the controlled-release of opioids from the delivery system are polymer composition and nanoparticle size. Additionally, their exposure medium can dramatically affect NPs degradation rates. Therefore, we studied the

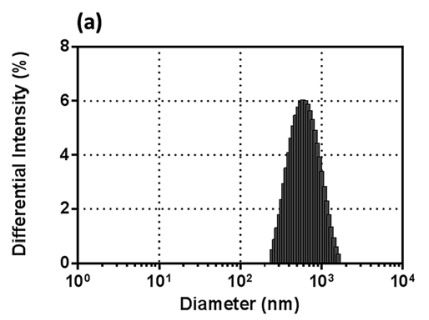

(b)

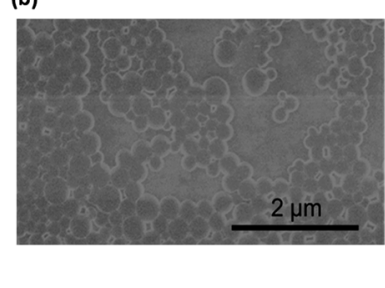

Fig. 4 Properties of Fen-PLGA NPs: (a) Fen-PLGA NPs size distribution, (b) ESEM image of uncoated Fen-PLGA NPs.

degradation rates of our covalent fentanyl NPs in two different buffers. We prepared NPs from Fen-PLA, Fen-PLGA and FenAcry-PLGA polymers, and studied the release of Fen-OH and Fen-Acry-OH (a metabolite of Fen-Acry-EtOH) in buffers with $\mathrm{pH}$ 7.4 (PBS) and pH 2 (KCl/HCl) (Fig. 5). The release was studied using RP-HPLC with a calibration curve generated from Fen$\mathrm{OH} /$ Fen-Acry-OH. As seen in Fig. 6, there is a clear relationship between the $\mathrm{pH}$ level and release rate for both PLA- and PLGA-based polymers. Moreover, as expected, the nanoparticle size influences the release rates of Fen-OH/Fen-Acry-OH. For instance smaller particle and lower $\mathrm{pH}$ caused more rapid release of fentanyl derivative.

The avoidance of the burst release kinetics is a key aspect of our covalently-loaded fentanyl nanoparticles. To confirm that covalent loading of Fen-OH was effective in avoiding the burst release, we prepared non-covalent Fen-OH loaded PLGA nanoparticles and studied the release of Fen-OH during 13 days period (Fig. 7). The maximum achievable concentration of noncovalent Fen-OH into the nanoparticles was $2 \%$, as compared to $5 \%$ for the covalently loaded particles. ${ }^{68}$ In future work we will examine the maximum loading of fentanyl into nanoparticles by lowering the molecular weight of the grafted polymer to increase the percent weight of fentanyl. Briefly, PLGA $75: 25$ with $M_{\mathrm{w}}$ of 76-115 $\mathrm{kDa}$ was co-dissolved with Fen-OH in dichloromethane (DCM). To obtain the similar sized nanoparticles with the covalent nanoparticles, same experimental conditions used for fabricating the covalent nanoparticles were followed for preparing the non-covalent nanoparticles. The only exception is that DCM rather than acetonitrile (ACN) was used as the solvent since ACN causes relatively fast release of noncovalent Fen-OH from nanoparticles.

The prepared nanoparticles are of $288 \pm 60 \mathrm{~nm}$ diameter and have a unimodal distribution with polydispersity of 0.15 (Fig. S14 in ESI $\dagger$ ), as determined by using dynamic light scattering (DLS). The release kinetics of Fen-OH from the non-

Table 1 ROP using fentanyl initiators

\begin{tabular}{|c|c|c|c|c|c|c|c|c|c|}
\hline Name & Monomer & Initiator & $\begin{array}{l}{[\text { Lactide }] /} \\
{[\text { glycolide }] /[\text { initiator }]}\end{array}$ & $\begin{array}{l}\text { Time } \\
(\min )\end{array}$ & $\begin{array}{l}M_{\mathrm{n}, \text { theo }} \\
\mathrm{kDa}\end{array}$ & $\begin{array}{l}M_{\mathrm{n}, \mathrm{GPC}} \\
\mathrm{kDa}\end{array}$ & $M_{\mathrm{w}} / M_{\mathrm{n}}$ & $\begin{array}{l}\text { Size }(\mathrm{nm}) \\
(\mathrm{PDI})\end{array}$ & $\begin{array}{l}\text { Zeta potential } \\
(\mathrm{mV})\end{array}$ \\
\hline Fen-PLA & Lactide & Fen-OH & $52 / 0 / 1$ & 120 & 7.9 & 9.5 & 1.35 & $362(0.190)$ & -32.89 \\
\hline Fen-PLGA & Lactide/glycolide & Fen-OH & $30 / 37 / 1$ & 120 & 9.0 & 14.0 & 2.45 & $563(0.135)$ & -19.83 \\
\hline Fen-Acry-PLGA & Lactide/glycolide & Fen-Acry-EtOH & $138 / 172 / 1$ & 20 & 40.2 & 16.3 & 1.65 & $508(0.100)$ & -22.03 \\
\hline
\end{tabular}



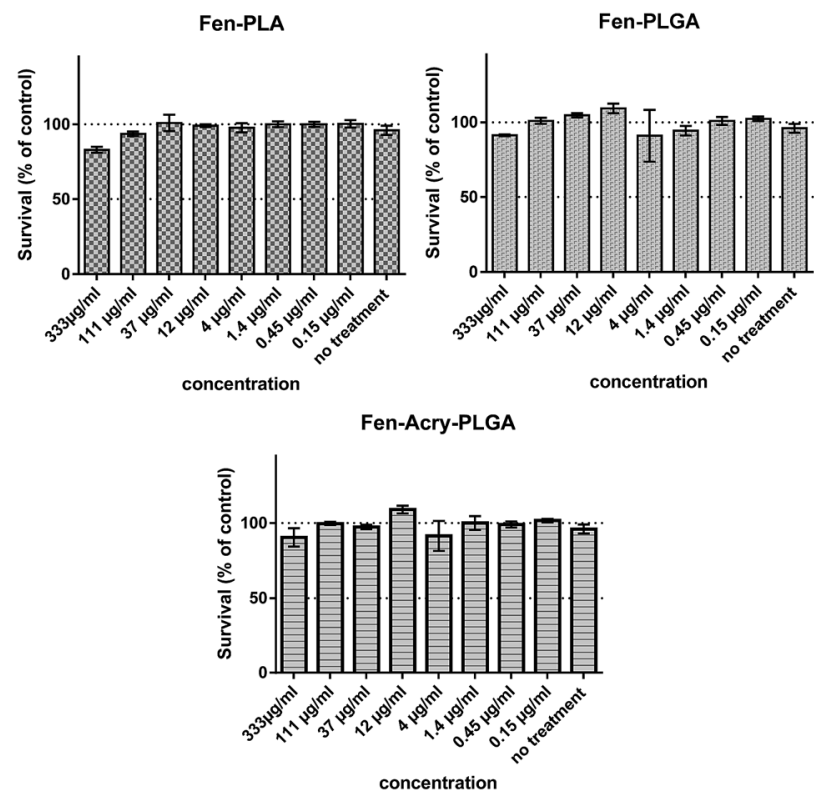

Fig. 5 Biocompatibility assays of Fen-PLA/PLGA NPs: biocompatibility assays were performed by incubating SH-SY5Y cells with the compounds for $48 \mathrm{~h}$ (as described in the Materials and methods section). Each point represents the ATP level as percent of control (untreated) cells, average of three replicates. Error bars represent triplicate variability.
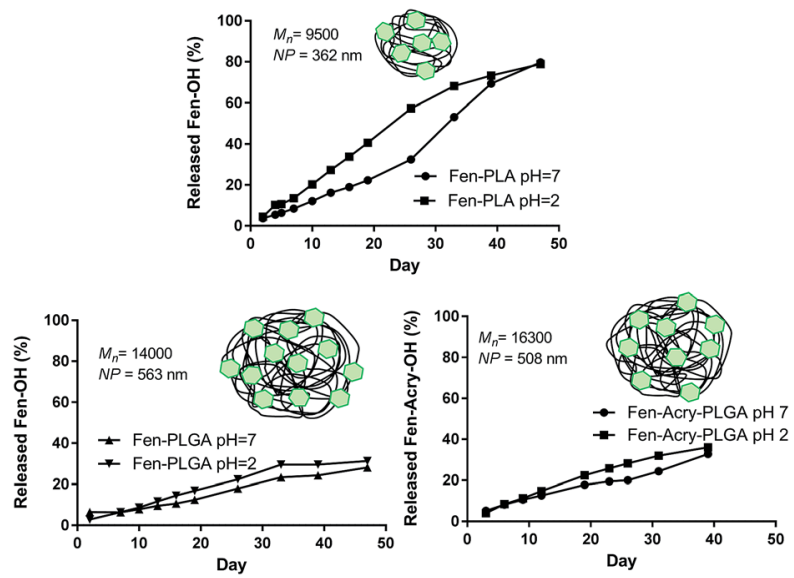

Fig. 6 Effect of the $\mathrm{pH}$ level of the buffer and nanoparticle size on Fen- $\mathrm{OH}$ and Fen-Acry-OH release from Fen-PLA and Fen-PLGA NPs.

covalent nanoparticles differs greatly from that of the covalent nanoparticles. Fen-OH-PLGA nanoparticles have initial burst release with non-linear release kinetics that results in greater than $80 \%$ of the total drug released after 4 days, and after 10 days near quantitative release occurred (Fig. 7). The covalent Fen-PLA nanoparticles, on the other hand, achieved linear release throughout the experimental period without any burst release (see Fig. 6). Avoiding this burst-release characteristic is critical to prevent abuse and potential euphoria. However, when desired, a particular release profile with some burst-release can be achieved by optimizing the amounts of covalent and noncovalent nanoparticles.

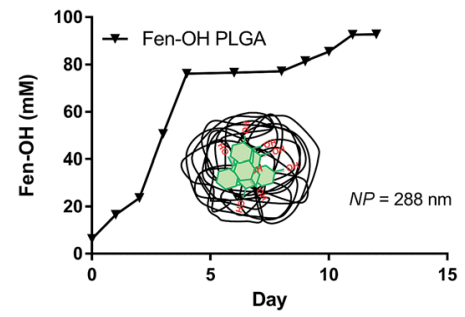

Fig. 7 Release kinetics of non-covalent Fen-OH (mM) from PLGA (75: 25) nanoparticles in PBS buffer $(\mathrm{pH}=7.4)$.

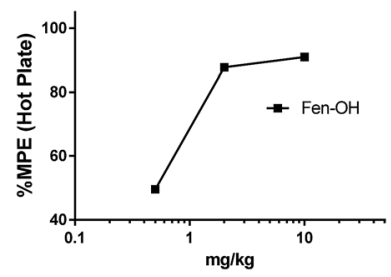

Fig. 8 Hot plate test: each point shows the \% of MPE induced by Fen$\mathrm{OH}$ at different concentrations.

\section{Multiday antinociceptive properties of Fen-PLA nanoparticles in vivo}

Before evaluating the properties of Fen-PLA NPs, the in vivo antinociceptive properties of Fen-OH were evaluated using an in vivo hot plate withdrawal assay (Fig. 7). Hot plate withdrawal assay is commonly used to corroborate analgesia due to its sensitivity and is largely employed to evaluate opioids. ${ }^{69}$ All animal care was performed in compliance with the Guide for the Care and Use of Laboratory Animals prepared by the Institute of Laboratory Animal Resources and published by the National Institutes of Health (NIH Publication no. 86-23), and was approved by Institutional Animal Care and Use Committee (IACUC) at Allegheny Health Network. Male CD-1 mice $(n=10)$ weighing $30 \mathrm{~g}$ were dosed subcutaneously 30 minutes prior to placement on a $55{ }^{\circ} \mathrm{C}$ hot plate and withdrawal latencies were measured (jumping or hind-paw licking) within a 30 second time frame. The maximum possible effect (MPE) at a $95 \%$ confidence interval was calculated according to the following equation: MPE $=100 \times\left(\right.$ time $_{\text {latency }}-$ time $\left._{\text {saline }}\right) /(30 \mathrm{~s}-$ time $_{\text {saline }}$. The MPE for Fen-OH was $50 \%$ at $0.5 \mathrm{mg} \mathrm{kg}^{-1}$ and $91 \%$ at $10 \mathrm{mg} \mathrm{kg}^{-1}$ (Fig. 8) compared to an MPE of $65 \%$ at $0.06 \mathrm{mg} \mathrm{kg}^{-1}$ of fentanyl (Fig. S19 in ESI†). These results indicate that Fen-OH has about two orders of magnitude lower activity than fentanyl, but is still well within the range of known opioids with an acceptable in vivo activity. ${ }^{70,71}$

The ability of Fen-PLA NPs to mitigate the sensation of pain was evaluated using acute nociceptive hot plate withdrawal assays. A single bolus subcutaneous dose of Fen-PLA NPs $\left(100 \mathrm{mg} \mathrm{kg}^{-1}\right) \sim 5 \mathrm{mg} \mathrm{kg}^{-1}$ equivalents of Fen-OH in $1 \times \mathrm{PBS}$ was delivered to 3 cohorts ( $n=10$ per cohort) of male CD 1 mice $(30 \mathrm{~g})$. The hot plate withdrawal latency was evaluated on days 1 , 6 and 14. Each cohort was tested independently and not reused. No change in mouse weight was observed throughout the testing period, indicating the biocompatibility of the Fen-PLA 
(a)

(b)
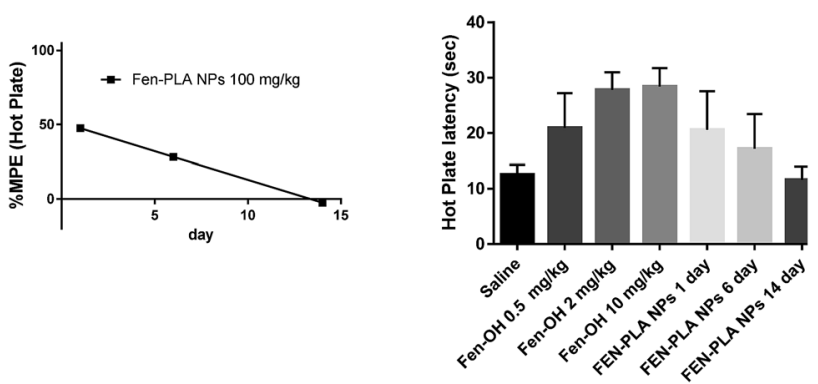

Fig. 9 Hot plate test: (a) each point shows the \% of MPE induced by Fen-PLA (NPs) during a 2 weeks period; (b) each column indicates latency of withdrawal (s) mean $\pm \operatorname{SEM}(n=10)$ at 30 min post dose of Fen-OH in different concentrations and during a 2 weeks period for Fen-PLA NPs (100 $\mathrm{mg} \mathrm{kg}^{-1}$ ).

NPs (Fig. S20 in ESI $\dagger$ ). From the hot plate nociceptive assay, we could achieve a $50 \%$ MPE on day $1, \sim 40 \%$ MPE on day 6 . By day 14, the therapeutic effect had been abrogated (Fig. 9). These results indicate the potential for the extended-release of opioids from a nanoparticle to provide sustained pain relief while avoiding multiple dosing.

The efficacy of the nanoparticle delivery system must be improved to achieve better localization of Fen-OH for providing a stable reservoir that can slowly elute opioids. Our current subcutaneous delivery method can potentially lead to unwanted absorbance and clearance of the NPs prior to release of the therapeutic opioids.

\section{Dissolvable microneedle arrays (MNA)}

The incorporation of the fentanyl NPs into microneedle arrays (MNA) could enable an effective and abuse-resistant delivery mechanism with an extended-release profile. To demonstrate the feasibility of this approach, the MNAs loaded with fentanyl NPs labelled with rhodamine were fabricated. Tip-loaded dissolvable MNAs with obelisk-shaped microneedles that incorporate the created opioid biohybrids were manufactured from CMC (carboxymethyl cellulose) using a micromilling/ elastomer-molding/spin-casting approach. ${ }^{\mathbf{6 1 , 6 2 , 6 5}}$ Bright field microscope images of the final tip-loaded MNAs (Fig. 9(a)) demonstrated the geometric integrity of the fabricated MNAs. Furthermore, tip localization of rhodamine-labelled opioid biohybrids was confirmed by fluorescence microscopy analysis (Fig. 9(b)).

\section{Conclusions}

In this paper, novel fentanyl based ROP initiators were prepared and used to grow PLA and PLGA NPs. The biodegradable fentanyl terminated polymers were characterized using GPC and ${ }^{1} \mathrm{H}$ NMR spectroscopy, demonstrating the successful preparation of well-defined opioid polymer hybrids. NPs from the fentanyl polymers were prepared via nanoprecipitation method. All fentanyl based polymer NPs were found to be fully biocompatible in the tested range. Additionally, we demonstrated that the fentanyl NPs can be integrated into tip-loaded dissolvable MNAs, leading to a viable strategy for eventual in vivo delivery. The Fen-PLA NPs were demonstrated to have sustained antinociceptive behavior up to day 6 in a mouse model of acute pain without unwanted burst-release. Our future studies will focus on testing the release kinetics and enhancing the therapeutic potency of fentanyl polymers in vivo.

\section{Conflicts of interest}

Author SA is listed as an inventor an on PCT/US2016/050398.

\section{Acknowledgements}

We gratefully thank the Allegheny Health Network Research Institute and the PA CURE grant (SAP\# 410007254) for start-up funds to conduct this research.

\section{References}

1 D. Dowell, T. M. Haegerich and R. Chou, J. Am. Med. Assoc., 2016, 315, 1624.

2 M. Miller, J. Am. Med. Assoc., 2012, 307, 1377.

3 R. Al-Hasani and M. R. Bruchas, Anesthesiology, 2011, 1, DOI: 10.1097/aln.0b013e318238bba6.

4 G. W. Pasternak and Y. X. Pan, Pharmacol. Rev., 2013, 65, 1257-1317.

5 J. Le Merrer, J. A. J. Becker, K. Befort and B. L. Kieffer, Physiol. Rev., 2009, 89, 1379-1412.

6 K. T. S. Pattinson, Br. J. Anaesth., 2008, 100, 747-758.

7 C. Martin, A. De Baerdemaeker, J. Poelaert, A. Madder, R. Hoogenboom and S. Ballet, Mater. Today, 2016, 19, 491502.

8 K. Simon, S. L. Worthy, M. C. Barnes and B. Tarbell, Ther. Adv. Drug Saf., 2015, 6, 67-79.

9 S. P. Stanos, P. Bruckenthal and R. L. Barkin, Mayo Clin. Proc., 2012, 87, 683-694.

10 L. Degenhardt, B. Larance, R. Bruno, N. Lintzeris, R. Ali and M. Farrell, Addiction, 2015, 110, 226-237.

11 M. K. Romach, K. A. Schoedel and E. M. Sellers, Drug Alcohol Depend., 2013, 130, 13-23.

12 R. A. Rudd, N. Aleshire, J. E. Zibbell and R. M. Gladden, MMWR Morb. Mortal. Wkly. Rep., 2016, 64, 1378-1382.

13 B. Setnik, C. L. Roland, J. M. Cleveland and L. Webster, Pain Med., 2011, 12, 618-631.

14 S. A. Seo, G. Khang, J. M. Rhee, J. Kim and H. B. Lee, J. Microencapsulation, 2010, 20, 569-579.

15 D. D. Jensen, T. Lieu, M. L. Halls, N. A. Veldhuis, W. L. Imlach, Q. N. Mai, D. P. Poole, T. Quach, L. Aurelio and J. Conner, Sci. Transl. Med., 2017, 9, eaal3447.

16 J. V. Pergolizzi Jr, R. B. Raffa, M. Pappagallo, C. Fleischer, J. Pergolizzi III, G. Zampogna, E. Duval, J. Hishmeh, J. A. LeQuang and R. Taylor Jr, Patient Prefer. Adherence, 2017, 11, 107.

17 C. Rivat and J. Ballantyne, Pain Rep., 2016, 1, e570. 
18 F. Y. Han, K. J. Thurecht, A. K. Whittaker and M. T. Smith, Front. Pharmacol., 2016, 7, 185.

19 S. K. Patel, W. Beaino, C. J. Anderson and J. M. Janjic, Clin. Immunol., 2015, 160, 59-70.

20 L. Brannon-Peppas, Int. J. Pharm., 1995, 116, 1-9.

21 M. Hans and A. Lowman, Curr. Opin. Solid State Mater. Sci., 2002, 6, 319-327.

22 J. Panyam and V. Labhasetwar, Adv. Drug Delivery Rev., 2003, 55, 329-347.

23 L. Pastorino, E. Dellacasa, P. Petrini and O. Monticelli, Mater. Sci. Eng., C, 2017, 1129-1135.

24 N. Thomas, C. Thorn, K. Richter, B. Thierry and C. Prestidge, J. Pharm. Sci., 2016, 105, 3115-3122.

25 T. G. Park, Biomaterials, 1995, 16, 1123-1130.

26 M. Vert, G. Schwach, R. Engel and J. Coudane, J. Controlled Release, 1998, 53, 85-92.

27 R. A. Jain, Biomaterials, 2000, 21, 2475-2490.

28 K. S. Soppimath, T. M. Aminabhavi, A. R. Kulkarni and W. E. Rudzinski, J. Controlled Release, 2001, 70, 1-20.

29 A. Kumari, S. K. Yadav and S. C. Yadav, Colloids Surf., B, 2010, 75, 1-18.

30 S. K. Sahoo, J. Panyam, S. Prabha and V. Labhasetwar, J. Controlled Release, 2002, 82, 105-114.

31 T. Görner, R. Gref, D. Michenot, F. Sommer, M. Tran and E. Dellacherie, J. Controlled Release, 1999, 57, 259-268.

32 D. A. Barrera, E. Zylstra, P. T. Lansbury and R. Langer, J. Am. Chem. Soc., 1993, 115, 11010-11011.

33 J. Davda and V. Labhasetwar, Int. J. Pharm., 2002, 233, 51-59.

34 J. Panyam and V. Labhasetwar, Pharm. Res., 2003, 20, 212220.

35 Y. Zhang, C. Wischke, S. Mittal, A. Mitra and S. P. Schwendeman, Mol. Pharm., 2016, 13, 2622-2630.

36 J. Nicolas, Chem. Mater., 2016, 28, 1591-1606.

37 R. Tong and J. Cheng, J. Am. Chem. Soc., 2009, 131, 47444754.

38 N. Kamaly, B. Yameen, J. Wu and O. C. Farokhzad, Chem. Rev., 2016, 116, 2602-2663.

39 M. L. Hans and A. M. Lowman, Curr. Opin. Solid State Mater. Sci., 2002, 6, 319-327.

40 A. W. Du and M. H. Stenzel, Biomacromolecules, 2014, 15, 1097-1114.

41 J. Panyam, D. Williams, A. Dash, D. Leslie-Pelecky and V. Labhasetwar, J. Pharm. Sci., 2004, 93, 1804-1814.

42 T. H. Stanley, J. Pain, 2014, 15, 1215-1226.

43 R. S. Vardanyan and V. J. Hruby, Future Med. Chem., 2014, 6, 385-412.

44 E. Zecca, A. Manzoni, F. Centurioni, A. Farina, E. Bonizzoni, D. Seiler, T. Perrone and A. Caraceni, Br. J. Clin. Pharmacol., 2015, 80, 110-115.

45 M. N. Pastore, Y. N. Kalia, M. Horstmann and M. S. Roberts, Br. J. Clin. Pharmacol., 2015, 172, 2179-2209.
46 L. Nelson and R. Schwaner, J. Med. Toxicol., 2009, 5, 230-241. 47 B. Nicholson, Pain Pract., 2009, 9, 71-81.

48 G. K. Gourlay, Lancet Oncol., 2001, 2, 165-172.

49 J. D. Tobias, Crit. Care Med., 1999, 27, 2262-2265.

50 B. Cai, H. Engqvist and S. Bredenberg, Int. J. Pharm., 2015, 488, 102-107.

51 C. K. Schauer, J. A. Shand and T. M. Reynolds, Basic Clin. Pharmacol. Toxicol., 2015, 117, 358-359.

52 H. Kucuk, U. Kucuk, Z. Kolcu, S. Balta and S. Demirkol, Hum. Exp. Toxicol., 2016, 35, 51-52.

53 R. Vanbever, J. Controlled Release, 1998, 50, 225-235.

54 I. Diaz del Consuelo, F. Falson, R. H. Guy and Y. Jacques, J. Controlled Release, 2007, 122, 135-140.

55 A. C. Anselmo and S. Mitragotri, J. Controlled Release, 2014, 190, 15-28.

56 J. Liaw and Y.-C. Lin, J. Controlled Release, 2000, 68, 273-282. 57 L. Allan, H. Hays, N.-H. Jensen, B. L. P. de Waroux, M. Bolt, R. Donald and E. Kalso, BMJ, 2001, 322, 1154.

58 S. Li, D. Cohen-Karni, M. Kovaliov, N. Tomycz, B. Cheng, D. Whiting and S. Averick, RSC Adv., 2017, 7, 20015-20019.

59 T. Tateishi, A. J. Wood, F. P. Guengerich and M. Wood, Biochem. Pharmacol., 1995, 50, 1921-1924.

60 O. Dechy-Cabaret, B. Martin-Vaca and D. Bourissou, Chem. Rev., 2004, 104, 6147-6176.

61 B. Bediz, E. Korkmaz, R. Khilwani, C. Donahue, G. Erdos, L. D. Falo and O. B. Ozdoganlar, Pharm. Res., 2013, 31, 117-135.

62 E. Korkmaz, E. E. Friedrich, M. H. Ramadan, G. Erdos, A. R. Mathers, O. Burak Ozdoganlar, N. R. Washburn and L. D. Falo, Acta Biomater., 2015, 24, 96-105.

63 R. F. Donnelly, T. R. R. Singh and A. D. Woolfson, Drug Delivery, 2010, 17, 187-207.

64 M. R. Prausnitz, Adv. Drug Delivery Rev., 2004, 56, 581-587.

65 E. Korkmaz, E. E. Friedrich, M. H. Ramadan, G. Erdos,

A. R. Mathers, O. B. Ozdoganlar, N. R. Washburn and L. D. Falo, J. Pharm. Sci., 2016, 105, 3453-3457.

66 M. Piotrowski, K. Szczepanowicz, D. Jantas, M. Lekiewicz, W. Laso and P. Warszyski, Nanoscale Res. Lett., 2013, 15, 1.

67 C. Hoskins, L. Wang, W. P. Cheng and A. Cuschieri, Nanoscale Res. Lett., 2012, 7, 77.

68 A. Kumari, V. Kumar and S. K. Yadav, PLoS One, 2012, 7, e41230.

69 L. Menendez, A. Lastra, A. Hidalgo and A. Baamonde, J. Neurosci. Methods, 2002, 113, 91-97.

70 R. o. Girón, R. Abalo, C. Goicoechea, M. I. Martín, L. F. Callado, C. Cano, P. Goya and N. Jagerovic, Life Sci., 2002, 71, 1023-1034.

71 C. Andrews and C. Prys-Roberts, J. Clin. Anesthesiol., 1983, 1, 97-112. 